\title{
Alkalinity Tolerance of Selected Provenances of Taxodium Rich.
}

\author{
Geoffrey C. Denny ${ }^{1,4}$ \\ Environmental Horticulture Department, University of Florida, IFAS Gulf \\ Coast REC, 14625 County Road 672, Wimauma, FL 33598-6101
}

Michael A. Arnold ${ }^{2}$

Department of Horticultural Sciences, Texas A\&M University, College Station, TX 77843-2133

\author{
Wayne A. Mackay ${ }^{3}$ \\ Environmental Horticulture Department, University of Florida, IFAS \\ Mid-Florida REC 2725 Binion Road, Apopka, FL 32703-8504
}

Additional index words. baldcypress, pondcypress, Montezuma cypress, Taxodium distichum, chlorosis, mineral nutrition, var. distichum, var. imbricarium, var. mexicanum

\begin{abstract}
Forty seedlings from each of 14 open-pollinated families of Taxodium distichum (L.) Rich. from the southeastern United States, central Texas, and south Texas/Mexico were evaluated in the summer of $\mathbf{2 0 0 5}$ for foliar chlorosis in a field situation with alkaline soil. The families from Mexico and south Texas had the lowest levels of chlorosis followed by those from central Texas and then those from the gulf coast. Height growth and trunk diameter were inversely related to chlorosis levels. Open-pollinated families from the gulf coast also had a significantly lower foliar manganese content on an alkaline field site compared with the western families. When selecting plant material for an alkaline site, genotypes from Mexico and south Texas should be preferred followed by central Texas genotypes.
\end{abstract}

Drought, salinity, and alkaline soils are common problems faced by many arborists, urban foresters, landscapers, and homeowners. Kelsey and Hootman (1990) found that many urban street tree planter soils could be classified as saline or sodic, soil types that usually occur in arid or semiarid areas with a higher evapotranspiration than precipitation rate. In many parts of the United States, drought and irrigation restrictions are becoming more common (Beeson et al., 2004). The combination of these problems necessitates the selection and use of more adapted tree species and genotypes in urban areas.

Taxodium distichum is a widely adaptable tree species for landscape use, tolerating both wet and dry soils and air pollution (Cox and Leslie, 1988; Wasowski and Wasowski, 1997). Watson (1983) reports tolerance to varying nutrient availability conditions, a wide range of soil aeration levels, and somewhat extreme $\mathrm{pH}$ levels. It is fast growing, has reliable feathery foliage, and a nice form (Arnold, 2002; Cox and Leslie, 1988). Two

\footnotetext{
Received for publication 7 Jan. 2008. Accepted for publication 6 Apr. 2008.

Funding for this study was provided by the TREE Fund, the J. Frank Schmidt Family Charitable Foundation, the Center for Landscape Plant Development, and the Texas Agricultural Experiment Station.

${ }^{1}$ Assistant Professor.

${ }^{2}$ Professor of Landscape Horticulture.

${ }^{3}$ Professor.

${ }^{4}$ To whom reprint requests should be addressed; e-mail gcdenny@ufl.edu
}

varieties, $T$. distichum var. distichum (baldcypress) and $T$. distichum var. imbricarium (Nutt.) Croom (pondcypress), have good fall color in some areas, whereas $T$. distichum var. mexicana Gordon (Montezuma cypress) remains semievergreen (Arnold, 2002). It is an extremely long-living tree with a lifespan of up to 700 years (Cox and Leslie, 1988). All of these factors allow $T$. distichum to tolerate many environmental stresses, making this species a promising choice for urban landscapes. However, there are a few limitations to this species. Although it is tolerant of substantial soil salt levels, it tends to defoliate when leaves come into contact with saline irrigation water, develop chlorosis on sites with high $\mathrm{pH}$ soils, and "brown out" in periods of extended or severe drought (Arnold, 2002).

Arnold (2002) defines ecotypic variation as "a distinct morphological or physiological form, or population, resulting from (natural) selection by a distinct ecological condition." It is the entire basis for provenance studies (Arnold, 2002). Zobel and Talbert (1984) define a provenance as "the original geographic area from which seed or other propagules were obtained" and equate it to the concepts of geographic source and geographic race. They also present a more useful definition of the concept as "a subdivision of a species consisting of genetically similar individuals, related by common descent, and occupying a particular territory to which it has become adapted through natural selection" (Zobel and Talbert, 1984). Provenances can be determined by numerous characteristics of the geographical origin, including latitude, altitude, precipitation, temperature, soil, and daylength (Zobel and Talbert, 1984). The identification of adapted provenances allows industry professionals to more closely tailor their plant selections to specific situations and can offer "the largest, cheapest and fastest gains" in tree improvement programs seeking an improved product for use in difficult ecophysiographic situations (Zobel and Talbert, 1984).

In forest management, the concept of seed source and provenance is widely recognized and used (Zobel and Talbert, 1984). However, in landscape horticulture and urban forestry, it is less widely used (Arnold, 2002). Some of the taxa studied in provenance research in this field include maple (Acer L.) spp. (St. Hilaire and Graves, 2001; Zwack et al., 1999), seaside alder [Alnus maritima (Marsh.) Muhl. ex Nutt.] (Schrader and Graves, 2000), pecan [Carya illinoinensis (Wangenh.) K. Koch] (Wood et al., 1998), Atlantic whitecedar [Chamaecyparis thyoides (L.) B.S.P.] (Jull et al., 1999), Amur maackia (Maackia amurensis Rupr.) (Pai and Graves, 1995), and sycamore (Platanus occidentalis L.) (Shoemake, 1996; Shoemake and Arnold, 1997).

The purpose of this study was to determine if there is a geographic basis for alkalinity tolerance in Taxodium distichum and to evaluate provenances in an effort to select those that could yield individuals that are most adaptable/tolerant to this environmental stress.

\section{Materials and Methods}

Fourteen open-pollinated families of Taxodium distichum were collected in the late summer and fall of 2003. Seeds from a single mother tree at several locations (Table 1; Fig. 1) representing the ecophysiographic variation throughout the central and western portion of the species range were collected and stratified $\left(90 \mathrm{~d}\right.$ at $\left.2{ }^{\circ} \mathrm{C}\right)$. Localities representing "normal" seed sources (mesic, acidic eastern U.S. sites) as well as sites representing more extreme environmental conditions (more xeric, alkaline western U.S. and Mexican sites) were sampled. Open-pollinated family identity was coded with four alphanumeric characters. The first two letters signify the general geographic origin of the mother tree. 'MX' signifies south Texas and Mexico, 'TX' signifies central Texas, and 'EP' denotes the southeastern United States. The numeral is unique to an open-pollinated family from a given geographic area. The final letter indicates the taxonomic variety. ' $\mathrm{M}$ ' indicates that the open-pollinated family belongs to $T$. distichum var. mexicanum, ' $\mathrm{D}$ ' indicates $T$. distichum var. distichum, and ' $\mathrm{I}$ ' indicates $T$. distichum var. imbricarium.

Seeds were planted on 12 Mar. 2004, and germination took place before the end of Apr. 2004. On 8 to 10 Apr. 2004, seedlings were transplanted into 2.5-L containers (Nursery Supplies, Inc., Kissimmee, FL) filled with 3 pine bark: 1 coarse perlite (by volume) mix 
Table 1. Localities of 14 mother trees providing seeds of open-pollinated families of Taxodium distichum collected in the late summer and fall of 2003 used in alkalinity screenings.

\begin{tabular}{llllr}
\hline Family & \multicolumn{1}{c}{ Latitude } & \multicolumn{1}{c}{ Longitude } & \multicolumn{1}{c}{ Locale } & $\mathrm{pH}^{z}$ \\
\hline MX1M & $25^{\circ} 52^{\prime} 48^{\prime \prime} \mathrm{N}$ & $97^{\circ} 27^{\prime} 0^{\prime \prime} \mathrm{W}$ & Southmost, TX & 7.8 \\
MX2M & $25^{\circ} 18^{\prime} 36^{\prime \prime} \mathrm{N}$ & $104^{\circ} 38^{\prime} 24^{\prime \prime} \mathrm{W}$ & Rio Nazas, Mexico & $\mathrm{NA}$ \\
MX4M & $27^{\circ} 51^{\prime} 0^{\prime \prime} \mathrm{N}$ & $101^{\circ} 7^{\prime} 48^{\prime \prime} \mathrm{W}$ & Rio Sabinas, Mexico & $\mathrm{NA}$ \\
MX5M & $26^{\circ} 4^{\prime} 12^{\prime \prime} \mathrm{N}$ & $97^{\circ} 54^{\prime} 36^{\prime \prime} \mathrm{W}$ & Progreso, TX & 7.8 \\
TX2D & $30^{\circ} \mathbf{\prime}^{\prime} 12^{\prime \prime} \mathrm{N}$ & $99^{\circ} 17^{\prime} 4^{\prime \prime} \mathrm{W}$ & Guadalupe River, TX & 7.2 \\
TX6D & $29^{\circ} 0^{\prime} 36^{\prime \prime} \mathrm{N}$ & $98^{\circ} 34^{\prime} 48^{\prime \prime} \mathrm{W}$ & Atascosa River, TX & 7.1 \\
TX7D & $29^{\circ} 46^{\prime} 12^{\prime \prime} \mathrm{N}$ & $98^{\circ} 8^{\prime} 24^{\prime \prime} \mathrm{W}$ & Guadalupe River, TX & $\mathrm{NA}$ \\
TX8D & $29^{\circ} 52^{\prime} 48^{\prime \prime} \mathrm{N}$ & $97^{\circ} 55^{\prime} 48^{\prime \prime} \mathrm{W}$ & San Marcos River, TX & 7.5 \\
EP1D & $32^{\circ} 20^{\prime} 24^{\prime \prime} \mathrm{N}$ & $94^{\circ} 42^{\prime} 0^{\prime \prime} \mathrm{W}$ & Lake Cherokee, TX & 7.2 \\
EP2D & $29^{\circ} 48^{\prime} 0^{\prime \prime} \mathrm{N}$ & $91^{\circ} 47^{\prime} 24^{\prime \prime} \mathrm{W}$ & Iberia Parish, LA & $\mathrm{NA}$ \\
EP4D & $30^{\circ} 36^{\prime} 0^{\prime \prime} \mathrm{N}$ & $87^{\circ} 54^{\prime} 36^{\prime \prime} \mathrm{W}$ & Mobile Bay, AL & 5.2 \\
EP5I & $30^{\circ} 27^{\prime} 0^{\prime \prime} \mathrm{N}$ & $88^{\circ} 6^{\prime} 36^{\prime \prime} \mathrm{W}$ & Fowl River, AL & 4.8 \\
EP6D & $30^{\circ} 24^{\prime} 36^{\prime \prime} \mathrm{N}$ & $88^{\circ} 54^{\prime} 0^{\prime \prime} \mathrm{W}$ & Biloxi, MS & 6.2 \\
EP8D & $31^{\circ} 33^{\prime} 36^{\prime \prime} \mathrm{N}$ & $91^{\circ} 26^{\prime} 24^{\prime \prime} \mathrm{W}$ & Mississippi River, LA & 7.0 \\
\hline
\end{tabular}

${ }^{\mathrm{z}}$ Soil samples were collected where possible to determine soil $\mathrm{pH}$ at the collection site. $\mathrm{NA}=$ not available

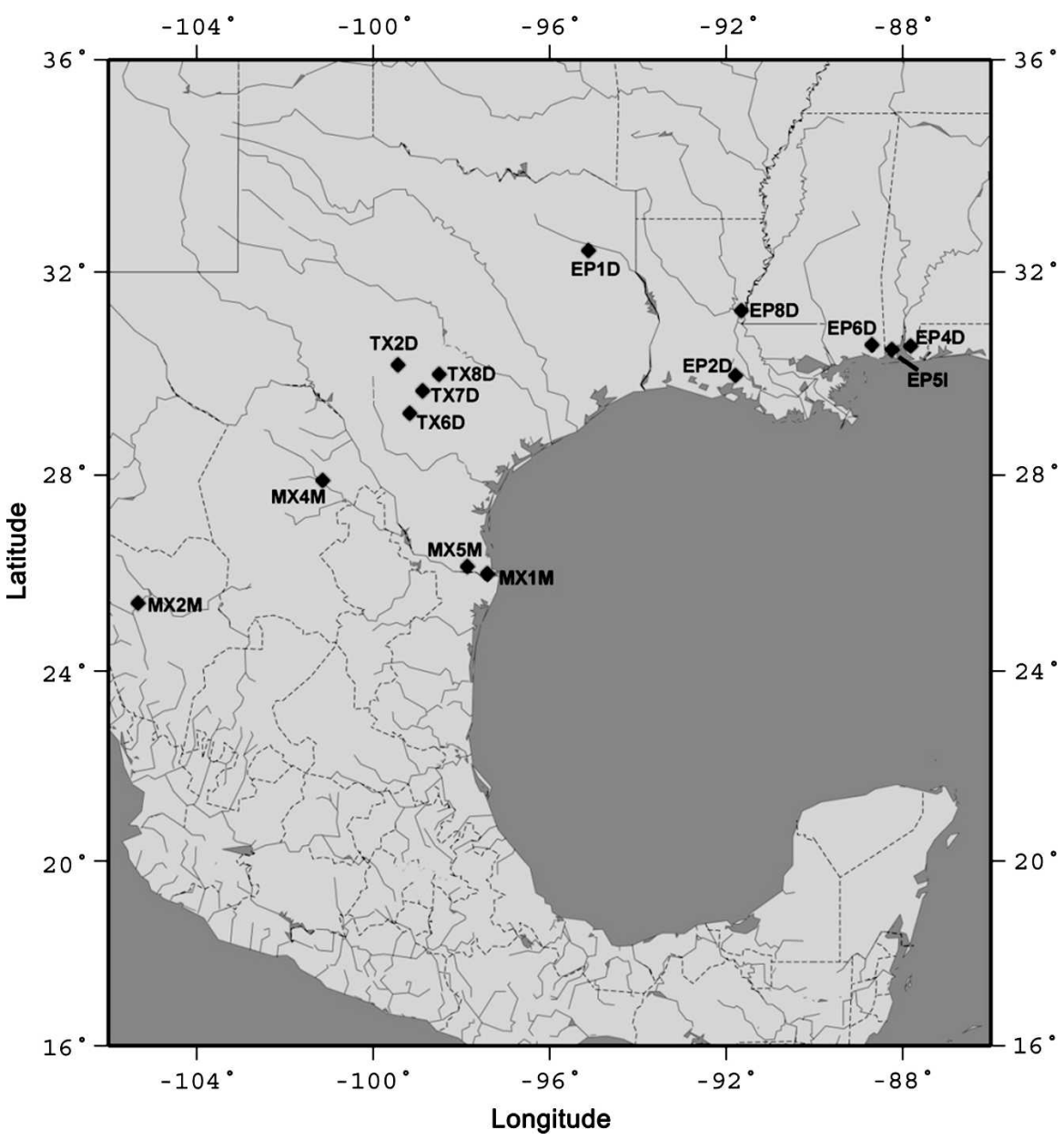

Fig. 1. Locations of mother trees providing seeds for open-pollinated families of Taxodium distichum used in alkalinity tolerance screenings. Open-pollinated family identities are indicated beside the symbols.

amended with $6.53 \mathrm{~kg} \cdot \mathrm{m}^{-3} 15 \mathrm{~N}-3.9 \mathrm{P}-9.9 \mathrm{~K}$ controlled-release fertilizer (Osmocote ${ }^{\circledR}$ Plus; Scotts Company, Marysville, $\mathrm{OH}), 0.89$ $\mathrm{kg} \cdot \mathrm{m}^{-3} 0 \mathrm{~N}-0 \mathrm{P}-0 \mathrm{~K}-6 \mathrm{Ca}-3 \mathrm{Mg}-12 \mathrm{~S}-17 \mathrm{Fe}$ micronutrient fertilizer $\left(\right.$ Micromax $^{\circledR}$; Scotts Company), $1.78 \mathrm{~kg} \cdot \mathrm{m}^{-3} \mathrm{CaSO}_{4}$ (United States Gypsum Co., Chicago, IL), and 4.15 $\mathrm{kg} \cdot \mathrm{m}^{-3} \mathrm{CaMgCO}_{3}$ (Oldcastle Stone Products,
Thomasville, PA). Plants were grown under $55 \%$ light exclusion in a nursery area and irrigated as needed.

Seedlings were planted in the field on 18 June 2004. Plants were arranged in a randomized complete block design with 14 families in 20 blocks containing two individuals from each family per block. The field site was located at the Texas A\&M Research and Extension Center at Dallas (USDA hardiness zone $8 \mathrm{a} / 7 \mathrm{~b}$ ). The soil at the site is an Austin silty clay (fine-silty, carbonatic, thermic, Udorthentic Haplustoll), $1 \%$ to $3 \%$ slopes, and has a $\mathrm{pH}$ of 8.0. The trees were irrigated using T-Tape (T-Systems International, Inc., San Diego, CA) as needed and no additional fertilizer was added. Tree heights and trunk diameters were measured $15.24 \mathrm{~cm}$ above the soil surface at the time of planting and again in Dec. 2004, 2005, and 2006. On 10 Aug. 2005 , the seedlings were rated by the first author on the level of foliar chlorosis they were exhibiting. The ratings were done on a four-point scale: 1 = very chlorotic, $2=$ slightly chlorotic, $3=$ green, and $4=$ very green .

Growth indices for both height and trunk diameter were calculated as follows: growth index $=($ new measure - previous measure $) /$ previous measure. This is analogous to relative growth rate calculations, except it is based on nondestructive measures rather than dry weights (Arnold et al., 2007). Most recently, matured leaves were sampled for tissue nutrient content analysis. Samples were collected on 22 Mar. 2007 from one plant from each of six open-pollinated families in three separate blocks. Three families (MX4M, MX5M, TX7D) were rated green or very green in the leaf chlorosis ratings. Families (EP1D, EP2D, EP4D) were rated as slightly to very chlorotic in the leaf chlorosis ratings. Tissue samples were submitted to the Texas A\&M University Soil, Water and Forage Testing Laboratory (College Station, TX) for nutrient analysis.

Height growth indices, trunk diameter growth indices, and leaf tissue nutrient contents were analyzed using univariate analysis in the GLM procedure and Pearson's correlation analysis in SPSS (version 12.0.2 for Windows; SPSS Inc., Chicago, IL). Chlorosis rating data were analyzed using $\chi^{2}$ analysis and Spearman's rho analysis. Hierarchical cluster analysis in SPSS using squared Euclidean distance and nearest-neighbor clustering based on both growth indices and the chlorosis rating data were used to generate dendrograms.

\section{Results and Discussion}

There was significant variation in the chlorosis and growth of open-pollinated families on the alkaline study site in Dallas, with open-pollinated families from the western portion of the range (central Texas and Mexico) performing better than those from the southeastern United States. The $\chi^{2}$ tests for chlorosis ratings and open-pollinated family were highly significant $(P \geq$ $0.0001)$. The percentage of individuals in a given open-pollinated family receiving each rating category indicated that families from Mexico and south Texas, which are $T$. distichum var. mexicana, generally had the most individuals with "greener" ratings (Fig. 2). Eastern families tended to have the most individuals with the most chlorotic ratings, 


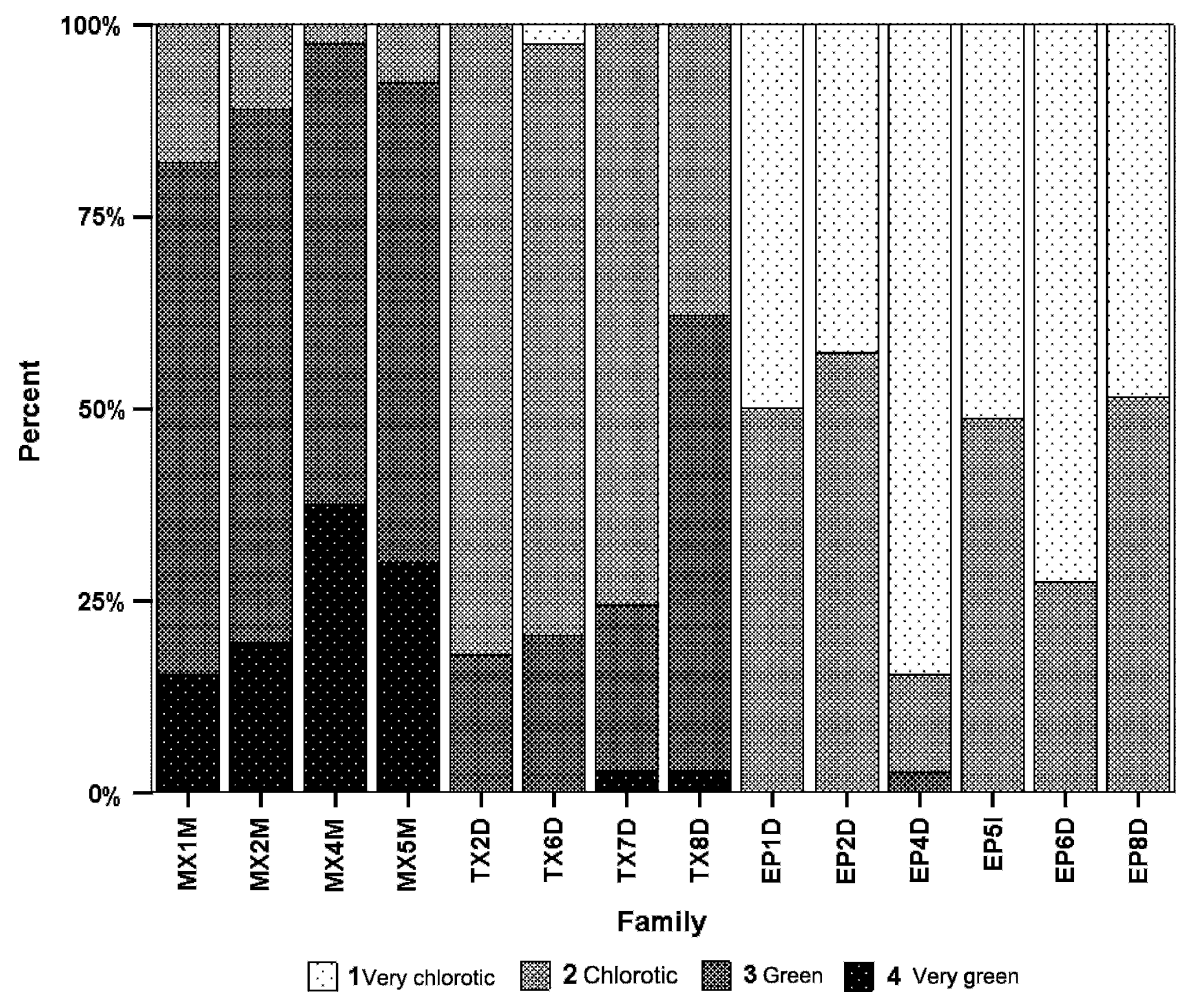

Fig. 2. Percentage of 40 individuals in each of 14 open-pollinated families that received a given rank on a chlorosis rating scale of 1 to 4 . The darker shades of the bar represents the relative darker shades of green of the plant; conversely, lighter shadings indicate more chlorotic plants.

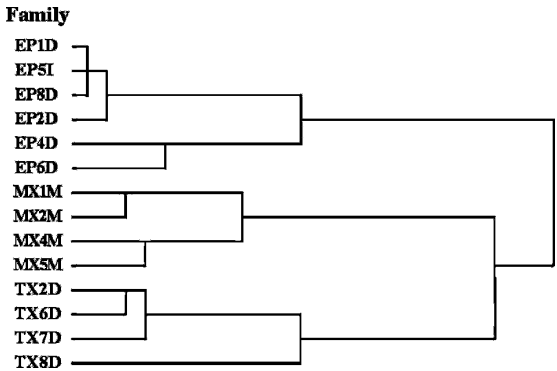

Fig. 3. Hierarchical cluster analysis dendrogram using complete linkage based on chlorosis ratings of 14 open-pollinated families of Taxodium distichum on an alkaline site in Dallas, TX. The shorter the horizontal branch length between open-pollinated families on the dendrogram, the more similar they are in relation to the parameters used in the analysis.

and the central Texas families were intermediate. This pattern was expected based on the general trend of increasing soil $\mathrm{pH}$ from east to west in the United States (Table 1). No obvious change in chlorosis pattern was seen in 2006. Marcar et al. (2002) reported a similar trend in high $\mathrm{pH}$ tolerance of Eucalyptus camaldulensis Dehnh. provenances in Australia. They report that seedlings from localities with higher soil $\mathrm{pH}$ showed less growth reduction when grown in substrates with a $\mathrm{pH}$ of 9.5. A hierarchical cluster analysis based on chlorosis ratings for each family suggests the existence of three groups as well (Fig. 3). However, growth data divide the families into just two groups (Figs. 4 and

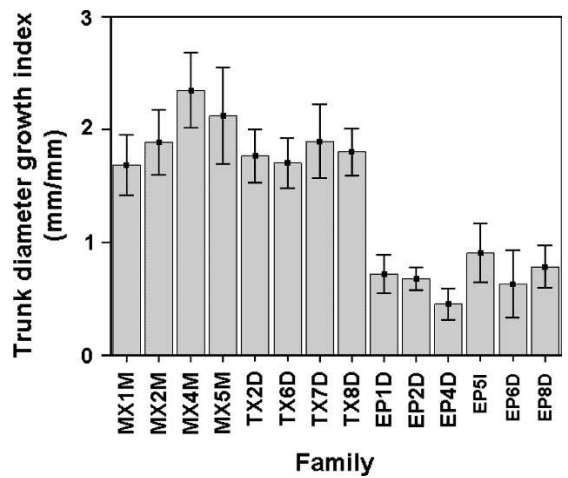

Fig. 4. Trunk diameter growth indices for the second season in the field (2005) of 14 openpollinated families of Taxodium distichum on an alkaline site in Dallas, TX. Values represent mean of 40 observations $\pm 95 \%$ confidence interval.

5; Table 2). The trunk diameter growth index $\left(R^{2}=0.795, P \leq 0.001\right)$ and height growth index $\left(R^{2}=0.604, P \leq 0.001\right)$ differed significantly among families. The trunk diameter growth index was larger for the central and south Texas and Mexican families than those from more eastern sites (Fig. 4). The same pattern exists for the height growth index (Fig. 5). When chlorosis ratings and both growth indices are used in hierarchical cluster analysis, three clusters are still evident, although the central Texas families cluster more closely with the Mexican families than in analyses based on chlorosis alone (Fig. 6). The biggest change in this cluster

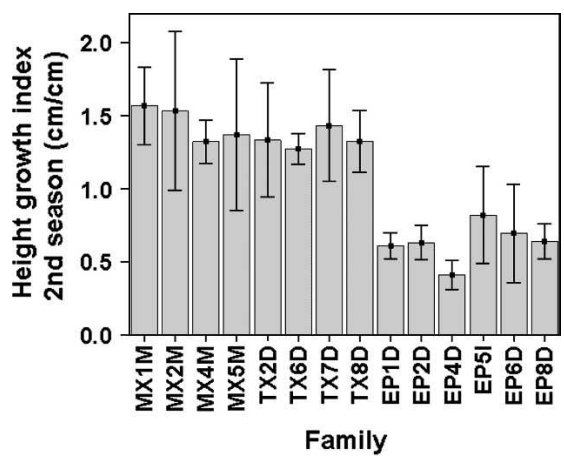

Fig. 5. Height growth indices for second season in the field (2005) of 14 open-pollinated families of Taxodium distichum on an alkaline site in Dallas, TX. Values represent mean of 40 observations $\pm 95 \%$ confidence interval.

Table 2. Final height and trunk diameter in 2006 of 14 open-pollinated families of Taxodium distichum on an alkaline site in Dallas, TX. ${ }^{\mathrm{z}}$

\begin{tabular}{lrc}
\hline Family & Ht $(\mathrm{cm})$ & $\begin{array}{c}\text { Trunk diam } \\
(\mathrm{mm})\end{array}$ \\
\hline MX1M & $175.5 \pm 35.6$ & $40.3 \pm 11.6$ \\
MX2M & $198.3 \pm 43.4$ & $42.1 \pm 14.6$ \\
MX4M & $215.6 \pm 32.3$ & $55.2 \pm 11.5$ \\
MX5M & $196.0 \pm 29.7$ & $53.1 \pm 11.7$ \\
TX2D & $157.3 \pm 32.9$ & $34.9 \pm 11.2$ \\
TX6D & $162.7 \pm 35.1$ & $38.8 \pm 9.9$ \\
TX7D & $137.4 \pm 30.5$ & $32.3 \pm 8.2$ \\
TX8D & $147.3 \pm 20.3$ & $37.8 \pm 7.8$ \\
EP1D & $109.2 \pm 19.2$ & $22.8 \pm 5.2$ \\
EP2D & $106.9 \pm 13.6$ & $19.3 \pm 4.2$ \\
EP4D & $92.2 \pm 18.6$ & $17.0 \pm 3.2$ \\
EP5I & $110.7 \pm 21.4$ & $21.6 \pm 5.1$ \\
EP6D & $92.1 \pm 19.0$ & $19.0 \pm 4.0$ \\
EP8D & $118.8 \pm 27.7$ & $23.2 \pm 6.1$ \\
\hline
\end{tabular}

${ }^{\mathrm{z}}$ Values represent mean of 40 observations \pm SD.

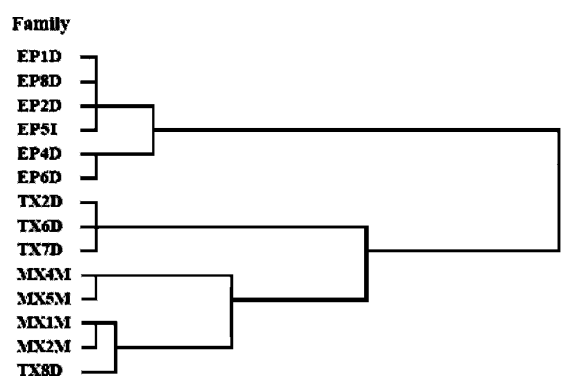

Fig. 6. Hierarchical cluster analysis dendrogram using complete linkage based on chlorosis ratings and trunk diameter growth index and height growth index of 14 open-pollinated families of Taxodium distichum on an alkaline site in Dallas, TX. The shorter the horizontal branch length between open-pollinated families on the dendrogram, the more similar they are in relation to the parameters used in the analysis.

analysis is the inclusion of family TX8D in the cluster of Mexican and south Texas families (Fig. 6). The noticeably "greener" ranking of family TX8D compared with other central Texas families (Fig. 2) likely accounts for this shift. A Spearman's rho correlation analysis indicates a strong relationship 
Table 3. Foliar tissue macronutrient and micronutrient content of six open-pollinated families of Taxodium distichum on an alkaline site in Dallas, $\mathrm{TX}^{\mathrm{z}}$.

\begin{tabular}{lcccccc}
\hline Family & $\begin{array}{c}\text { Nitrogen } \\
(\%)\end{array}$ & $\begin{array}{c}\text { Phosphorus } \\
(\%)\end{array}$ & $\begin{array}{c}\text { Potassium } \\
(\%)\end{array}$ & $\begin{array}{c}\text { Zinc } \\
\left(\mathrm{mg} \cdot \mathrm{L}^{-1}\right)\end{array}$ & $\begin{array}{c}\text { Copper } \\
\left(\mathrm{mg} \cdot \mathrm{L}^{-1}\right)\end{array}$ & $\begin{array}{c}\text { Manganese } \\
\left(\mathrm{mg} \cdot \mathrm{L}^{-1}\right)\end{array}$ \\
\hline MX4M & $5.48 \pm 1.37$ & $0.41 \pm 0.03$ & $0.77 \pm 0.04$ & $31.33 \pm 4.73$ & $8.67 \pm 0.58$ & $157.67 \pm 56.41$ \\
MX5M & $5.26 \pm 0.90$ & $0.34 \pm 0.02$ & $0.73 \pm 0.05$ & $34.33 \pm 4.93$ & $9.33 \pm 2.31$ & $126.67 \pm 32.96$ \\
TX7D & $6.18 \pm 0.48$ & $0.61 \pm 0.06$ & $1.08 \pm 0.23$ & $67.00 \pm 14.00$ & $14.33 \pm 2.08$ & $202.00 \pm 84.59$ \\
EP1D & $5.44 \pm 0.61$ & $0.71 \pm 0.11$ & $1.70 \pm 0.22$ & $79.67 \pm 4.73$ & $18.33 \pm 3.21$ & $70.00 \pm 4.00$ \\
EP2D & $4.19 \pm 0.24$ & $0.56 \pm 0.10$ & $1.28 \pm 0.16$ & $71.67 \pm 16.50$ & $14.67 \pm 3.51$ & $58.33 \pm 14.47$ \\
EP4D & $5.09 \pm 0.65$ & $0.65 \pm 0.16$ & $1.33 \pm 0.31$ & $62.00 \pm 10.15$ & $17.33 \pm 3.21$ & $66.33 \pm 15.31$ \\
\hline
\end{tabular}

${ }^{2}$ Values represent mean of three observations \pm SD.

between open-pollinated family and chlorosis rating $\left(R^{2}=-0.753, P \leq 0.001\right)$ and chlorosis rating and both height growth index $\left(R^{2}=0.526, P \leq 0.001\right)$ and trunk diameter growth index $\left(R^{2}=0.598, P \leq\right.$ 0.001). A Pearson's correlation analysis also indicates a relationship between openpollinated family and both height growth index $\left(R^{2}=-0.334, P \leq 0.001\right)$ and trunk diameter growth index $\left(R^{2}=-0.506, P \leq 0.001\right)$.

Significant differences $(P \leq 0.01)$ in leaf tissue nutrient concentrations were observed among open-pollinated families for nitrogen, phosphorus, potassium, zinc, copper, and manganese (Table 3). Generally, the three slower-growing eastern open-pollinated families had higher foliar nutrient concentrations compared with the faster-growing western open-pollinated families. Dilution effects resulting from the rapid growth rate of the western families likely account for the lower concentrations relative to the slower-growing eastern families. A notable exception to this pattern is the leaf tissue manganese concentrations of the western open-pollinated families, which were higher compared with the eastern families. The more chlorotic ratings of the eastern families and the lower concentrations of manganese in leaf tissue suggest that the observed chlorosis may be associated with these differential manganese concentration.

This field study provided a reliable and efficient screening technique, allowing large numbers of plants to be evaluated in a "realworld" situation. This reliability and efficiency allowed for a clear illustration of the geographic component to alkalinity tolerance in Taxodium distichum. Interestingly, Wood et al. (1998) found a similar geographic pattern for zinc deficiency in pecan [Carya illinoinensis (Wangenh.) K. Koch] provenances. They found that Texas and Mexican provenances tended to cluster together, separate from sources north and east of Texas. Their results were surprising because it indicated that provenances from areas with more alkaline soils (Mexico and Texas) showed higher levels of zinc deficiency. They attributed this to differential growth rates, indicating that the faster growth of the Texas and Mexican provenances was causal rather than physiological use or uptake efficiency of zinc.
Several other authors have investigated the effect of provenance on environmental adaptability within a species. Zwack et al. (1999) and St. Hilaire and Graves (2001) found differences in drought tolerance of maple (Acer L.) spp. Jull et al. (1999) found that provenances of Atlantic whitecedar [Chamaecyparis thyoides (L.) B.S.P.] varied in heat tolerance. Provenance affected nitrogen fixation in Amur maackia (Maackia amurensis Rupr.) (Pai and Graves, 1995). Provenances of sycamore (Platanus occidentalis $\mathrm{L}$.) varied in root growth, establishment, and nursery performance (Shoemake, 1996; Shoemake and Arnold, 1997).

Taxonomic ranking also seems to correlate with performance on an alkaline site. This is to be expected, because varietal status in this species has a strong geographic component (Denny and Arnold, 2007). Genotypes from south Texas and Mexico all belong to $T$. distichum var. mexicana. All of the genotypes in central Texas are $T$. distichum var. distichum. The vast majority of the sampled eastern genotypes are also T. distichum var. distichum, the exception being family EP5I from the Fowl River in Alabama. This family was $T$. distichum var. imbricarium. Montezuma cypress seems to be more tolerant of an alkaline site than the other varieties. If this variety is excluded, and T. distichum var. distichum is considered alone, there is still a strong geographic component to the variation in tolerance of alkaline soils.

In conclusion, care should be taken to select genotypes from regions shown to yield tolerant individuals. When selecting plant material for an alkaline site, genotypes from Mexico and south Texas should be preferred followed by central Texas genotypes. The probable greater cold-hardiness of genotypes from central Texas based on their more northern latitudes may dictate their use in preference over the south Texas and Mexican genotypes on alkaline sites in colder regions.

\section{Literature Cited}

Arnold, M.A. 2002. Landscape plants for Texas and environs, sec. ed. Stipes Publ. L:L.C., Champaign, IL.
Arnold, M.A., G.V. McDonald, D.L. Bryan, G.C. Denny, W.T. Watson, and L. Lombardini. 2007. Below-grade planting adversely affects survival and growth of tree species from five different families. Arboriculture and Urban Forestry 33:64-69.

Beeson, R.C., Jr., M.A. Arnold, T.E. Bilderback, B. Bolusky, S. Chandler, H.M. Gramling, J.D. Lea-Cox, J.R. Harris, P.J. Klinger, H.M. Mathers, J.M. Ruter, and T.H. Yeager. 2004. Strategic vision of container nursery irrigation in the next ten years. J. Environ. Hort. 22:113115.

Cox, P.W. and P. Leslie. 1988. Texas trees: A friendly guide. Corona Publ. Co., San Antonio, TX

Denny, G.C. and M.A. Arnold. 2007. Taxonomy and nomenclature of baldcypress, pondcypress and montezuma cypress: One, two or three species? HortTechnology 17:125127.

Jull, L.G., T.G. Ranney, and F.A. Blazich. 1999. Heat tolerance of selected provenances of Atlantic white cedar. J. Amer. Soc. Hort. Sci. 124:492-497.

Kelsey, P. and R. Hootman. 1990. Soil resource evaluation for a group of sidewalk street tree planters. J. Arboric. 16:113-117.

Marcar, N.E., Y. Zohar, J. Guo, and D.F. Crawford. 2002. Effect of $\mathrm{NaCl}$ and high $\mathrm{pH}$ on seedling growth of 15 Eucalyptus camaldulensis Dehnh. provenances. New For. 23:193-206.

Pai, J.G.B. and W.R. Graves. 1995. Seed source affects seedling development and nitrogen fixation of Maackia amurensis. J. Environ. Hort. 13:142-146.

Schrader, J.A. and W.R. Graves. 2000. Seed germination and seedling growth of Alnus maritima from its three disjunct populations. J. Amer. Soc. Hort. Sci. 125:128-134.

Shoemake, L.J. 1996. Effects of half-sib family selection on the root regeneration potential and initial landscape establishment of containergrown sycamore, Platanus occidentalis L. Texas A\&M Univ., College Station, TX. MS Thesis.

Shoemake, L.J. and M.A. Arnold. 1997. Half-sib family selection improves container nursery and landscape performance of sycamore. J. Environ. Hort. 15:126-130.

St. Hilaire, R. and W.R. Graves. 2001. Stability of provenance differences during development of hard maple seedlings irrigated at two frequencies. HortScience 36:654657.

Wasowski, S. and A. Wasowski. 1997. Native Texas plants: Landscaping region by region. Gulf Publishing Co., Houston, TX.

Watson, F.D. 1983. A taxonomic study of pondcypress and baldcypress. North Carolina State University, Raleigh, NC. PhD Diss.

Wood, B.W., L.J. Grauke, and J.A. Payne. 1998. Provenance variation in pecan. J. Amer. Soc. Hort. Sci. 123:1023-1028.

Zobel, B. and J. Talbert. 1984. Applied forest tree improvement. Waveland Press, Inc., Prospect Heights, IL. p. 58-116.

Zwack, J.A., W.R. Graves, and A.M. Townsend. 1999. Variation among red and freeman maples in response to drought and flooding. HortScience 34:664-668 